\begin{tabular}{|ccc}
\hline Sournals & $\begin{array}{c}\text { INTERNATIONAL JOURNAL OF } \\
\text { ORGANIZATIONAL LEADERSHIP }\end{array}$ & $\begin{array}{c}\text { INDUSTRIAL } \\
\text { MANAGEMENT } \\
\text { INSTITUTE }\end{array}$ \\
\hline \hline
\end{tabular}

\title{
Family firms, expropriation and firm value: Evidence of the role of independent directors' tenure in Malaysia
}

\author{
Chee Yoong Liew ${ }^{1 *}$, Ervina Alfan ${ }^{2}$, Susela Devi ${ }^{3}$ \\ ${ }^{1}$ SEGi University, Malaysia \\ ${ }^{2}$ University of Malaya, Malaysia \\ ${ }^{3}$ UNITAR International University, Malaysia
}

\begin{tabular}{l}
\hline \\
Keywords: \\
Corporate Governance, \\
Expropriation, Family \\
Firms, Agency Problems \\
\hline Received \\
21 July 2016 \\
Received in revised form \\
19 September 2016 \\
Accepted \\
13 October 2016 \\
\hline
\end{tabular}

\section{Abstract}

\begin{abstract}
This paper was conducted to examine whether there was a negative relationship between independent directors' tenure and firm value which indicated the existence of expropriation due to long tenure of independent directors and whether controlling shareholders' ownership moderated this relationship among Malaysian firms. The results revealed that there was a negative relationship between independent directors' tenure and firm value. It also showed there was a significant positive moderating effect of controlling shareholders' ownership on the relationship among Malaysian family firms in exclusive industries. However, there was inconclusive evidence that this negative relationship and positive moderating effect were stronger amongst the family firms compared with non-family firms.
\end{abstract}

Correspondence:

cheeyoong1@gmail.com

(C)AIMI Journals

Most corporate governance discussions center on traditional shareholder-manager problems or agency problem type I. These discussions typically assume that greater insider ownership leads to better corporate governance (Morck \& Yeung, 2003) because managers who own large blocks of shares in their firms are less likely to take actions which reduce the value of their shares (Jensen \& Meckling, 1976). This mitigation framework is certainly true in the most developed economies whereby ownership structures are very much diffuse (Morck \& Yeung, 2003). However, this framework may not work in emerging markets where ownership structure is highly concentrated and most of them are family-controlled firms. 
Such ownership structure in emerging markets coupled with the absence of effective external governance mechanisms; result in frequent conflicts between controlling shareholders and minority shareholders or agency problem type II (Morck, Wolfenzon \& Yeung, 2005; Villalonga \& Amit, 2006). Despite the considerable literature on corporate governance, particularly with respect to Agency Problem Type I, there is still a lot that remains to be understood with regards to issues of expropriation and Agency Problem Type II (Bjuggren, Johansen, \& Sjogren, 2011; Cascino, Pugliese, Mussolino \& Sansone, 2010; Jiang, Lee, \& Yue, 2010). In most expropriation studies, expropriation indirectly refers to the effects of the separation of ownership and control rights of the firm's major shareholders or controlling shareholders over its control rights towards the firm value (Krishnamurti, Sevic \& Sevic, 2005; Mitton, 2002) and rate of dividends paid to shareholders (Faccio, Lang, \& Young, 2001; La Porta, Lopez-de-Silanes, Shleifer, \& Vishny, 2000). Furthermore, economists also measure the effects of expropriation indirectly either through the price paid for corporate control or from changes in firms' market value around specific events. While these studies have clearly shown the existence of expropriation, but very little empirical evidence has been provided about the existence of expropriation due to long tenure across independent directors (Jiang, Lee, \& Yue, 2010).

According to Ahrens, Filatochev, and Thomsen (2011) in majority of expropriation studies, the extant of corporate governance fails to evidence the moderating role of internal corporate governance mechanisms. Hence, the moderating effects of internal corporate governance mechanism opens up a new avenue for research to enhance our understanding and firms' views of corporate governance implications of concentrated ownership such as controlling shareholders' ownership concentration on the relationship between firm value and other variables (Cascino et.al 2010; Holderness \& Sheehan, 1988; Short, 1994) particularly with respect to the cost of large shareholders (Claessens, Djankov, Fan \& Lang, 2002). Based on prior research in governance and accounting, this paper tried to assess the role of family ownership on the expropriation. Most prior studies are used to investigate the US equity market where listed firms are predominantly widely-held. This study was conducted to exploit the features of the Malaysian equity market which is characterized by high levels of ownership concentration (Claessens, Djankov, \& Lang, 2000). Generally, Malaysian cooperations evidence four main parts of ownership structures, namely family, governmentlinked, other types of corporate shareholders as well as widely held corporations (Ishak \& Napier, 2006). This paper empirically investigated whether controlling shareholders' ownership concentration moderates the relationship between independent directors' tenure and firm value. Whilst prior studies which investigated the moderating impact of other internal corporate governance mechanisms on this relationship are limited to evidence of the ownership concentration role. The literature review on family business governance and corporate governance is presented in three parts. First, it explores a relatively unexplored issue of expropriation, i.e., the effects of independent director's tenure on the firm value. Second, it evidences the moderating role of family ownership on the relationship between independent directors' tenure and firm value. In the third part, it shows the positive impact of family ownership on the relationship between independent directors' tenure and firm value. 


\section{The Review of Literature}

\section{Corporate Governance Development and Regulatory Framework}

One of the major causes of post-1997 Asian financial crisis corporate governance was the reforms in the Malaysian Code on Corporate Governance (MCCG) which was established in 2000. The World Bank in its assessments on the observance of Corporate Governance codes in Malaysia since 2001 observed that Malaysia has faced several challenges in improving its corporate governance practices due to its institutional setting. It was highlighted that the government's level of equity ownership has remained large, whilst free float has remained low and directors' accountability and protection for minority shareholders were significantly low. Furthermore, the role of institutional investors and shareholder activism in the corporate governance framework were weak. According to World Bank reports during 2001 and 2005, the corporate governance landscape in Malaysia transformed significantly as firms enhanced their corporate governance systems. These initiatives made a difference when Malaysian firms with concentrated ownership produced better accounting results (Haniffa \& Hudaib, 2006). After outlining the reports of World Bank in 2005 on the inadequacies of the corporate governance reforms, the code was revised in 2007. The Malaysian Code on Corporate Governance 2007 (MCCG 2007) emphasized on strengthening the board of directors and audit committees and ensuring that the board of directors and audit committees discharge their duties and responsibilities effectively. To sustain the corporate governance climate, the Securities Commission (SC) published the Corporate Governance Blueprint 2011 in 2011. This blueprint further focuses on the exercise of shareholder rights, role of institutional investors, board's role in governance, improving disclosure and transparency, role of gatekeepers and influencers, as well as public and private enforcement. To spearhead the Corporate Governance Blueprint 2011, the Securities Commission further revised the MCCG 2007 in 2012. The MCCG 2012 which supersedes the 2007 code, sets out principles, structures, and processes for companies' board so that the board could incorporate good corporate governance into their firms' business dealings and corporate culture. Despite the issuance of the MCCG in 2000, 2007, and 2012, these codes of corporate governance possibly are ineffective for improving corporate governance, i.e., reducing minority shareholder expropriation due to the voluntary nature of its adopted principles (Aguilera \& CuervoCazurra, 2009). In Malaysia, the controlling shareholders possibly consider the adoption of these principles obligatory, and this offers them some kind of incentives to expropriate minority shareholders, even though, they are still required to state the extent of their compliance in their annual reports, with an explanation for any departure (Wahab et. al., 2007). Apart from MCCG, the Bursa Malaysia listing requirements is another mechanism in promoting good corporate governance among Malaysian public-listed firms. However, unlike the MCCG which is voluntary, these requirements are mandatory. Bursa Malaysia has the power to reprimand, fine, or suspend the listed firms and/or its defaulting dealers. Furthermore, it has the power to issue a warning letter, private or public reprimand, impose a fine, suspend the trading, or delist an issuer from the official list of the exchange. However, the complemented powers and activities at Bursa Malaysia are always subject to judicial review. Although the listing requirements in Bursa Malaysia can be argued to be as effective mechanisms in promoting good corporate governance, it is not entirely effective due to the possibility of judicial 
review of its decisions (Shim, 2006). Hence, this may provide opportunities for controlling shareholders to expropriate minority shareholders because they view that the disciplinary actions taken by Bursa Malaysia reduce the judicial efficiency (Klapper \& Love, 2004). Another important corporate governance development in Malaysia is the creation of external corporate governance mechanisms to ensure fair and equitable treatment and protection of minority shareholders' rights (Wahab et al., 2011). To monitor and protect the rights of minority shareholders and promote shareholder activism, the High Level Finance Committee recommended the establishment of the Minority Shareholder Watchdog Group (MSWG) in February, 1999 (Wahab et al., 2011). The main roles of the MSWG are to act as a platform in starting collective shareholder activism on unethical practices by management of public-listed firms, improving and monitoring the corporate governance practices by the breaches of public-listed companies, and providing training programs to promote shareholder activism and the benefits of practicing good corporate governance principles (Wahab et al., 2011). With the formation of MSWG, it is expected that the expropriation of minority shareholders can be reduced because this is one avenue of market discipline to encourage good corporate governance among public listed companies. However, the effectiveness of the MSWG in reducing the problem of minority shareholder expropriation is disputable because unlike the Securities Commission (SC), it does not possess the legal authority to bring cases of minority shareholder expropriation to the court. Its main role is only to promote shareholder activism to protect the rights of minority shareholders through acting as external monitors of corporate governance practices in public- listed firms. Therefore, the role of the MSWG in reducing the problem of minority shareholder expropriation may not be effective. Therefore, the problem of minority shareholder expropriation may still persist in Malaysia. However, it must be noted that the Bursa Malaysia introduced several corporate governance initiatives to raise the standards of corporate governance practices among the listed firms, and the minority shareholders watchdog group (MSWG) introduced a Malaysian Corporate Governance (MCG) index to promote the best practices in corporate governance among listed firms in 2009. Nevertheless, to this date, there is limited evidence to suggest that these reform initiatives have been beneficial.

\section{Minority Shareholder Expropriation}

Malaysia is an emerging market which possesses very different ownership and control structures compared to developed economies. Yunos, Smith, and Ismail (2010) found that between 20012007, 96.8 per cent of Malaysian public listed firms are closely held by controlling shareholders. They also found that 30.8 per cent of public listed firms are controlled by management whereby the managers remain as appointees of controlling shareholders. The high concentration on ownership and control structures of firms in Malaysia provide opportunities for controlling shareholders to expropriate minority shareholders which lead to principal-principal conflicts due to the loss of investor protection compared to developed countries (Claessens et al., 2000, Young et al., 2008). The principal-principal conflict or agency problem type II has been identified as a major corporate governance issue in emerging markets (Young et al., 2008). This conflict occurs between two groups of principals including controlling and 
minority shareholders (Jiang \& Peng, 2011). Young et al. (2008) stated that the principalprincipal conflict is considered to be severe when the firm is owned and controlled by one large shareholder. The principal-principal conflict in emerging markets differs from the principal-agent problem that is prevalent in developed economies. Figure 1 explained this difference briefly.

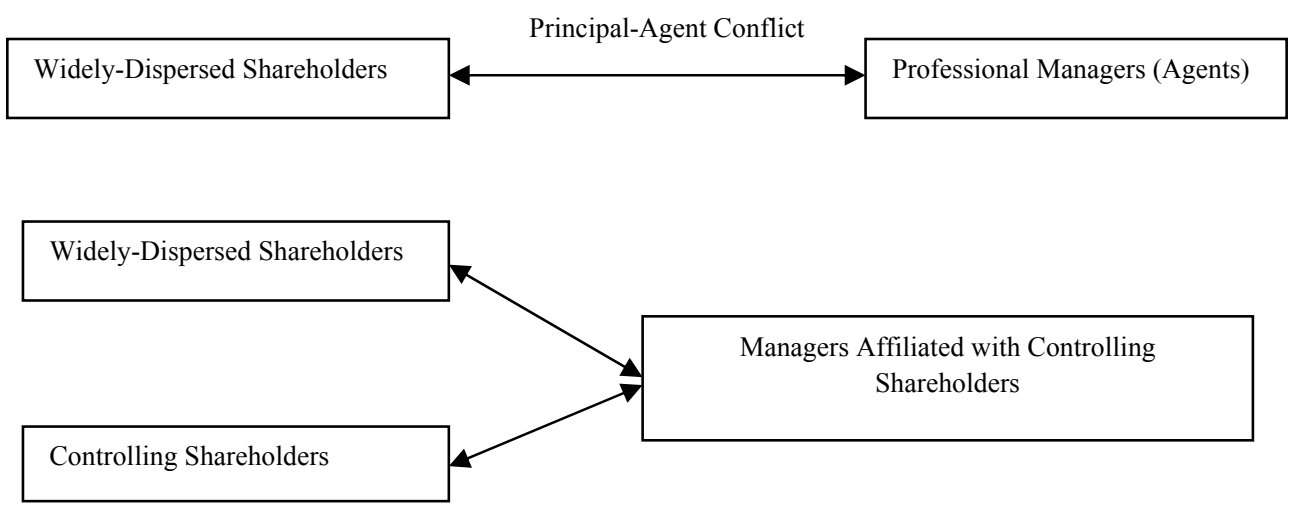

Figure 1. The difference between principal-principal and principal-agent conflicts

In the top panel of Figure 1, the arrow depicts the traditional principal-agent conflict that occurs between dispersed shareholders and professional managers. In the bottom panel of Figure 1, the slanted arrow depicts the relationship between the controlling shareholders and their affiliated managers. These affiliated managers may be family members or close associates who reports directly to the controlling shareholders. Furthermore, the straight line depicts the conflict which is drawn between the affiliated managers who represent the controlling shareholders and the minority shareholders. Hence, the conflict actually is between the controlling shareholders on one hand and dispersed minority shareholders on the other hand (Young et al., 2008). One of the ways for expropriating the minority shareholders or inducing principal-principal conflict is obtained through independent directors' tenure. Long tenure of independent directors may provide opportunities for controlling shareholders and influencing the independent directors in order to expropriate resources from the firm at the expense of minority shareholders.

\section{Independent Director's Tenure and Firm Value}

A large empirical literature investigates the benefits and costs of directors' tenure (O'Reilly \& Caldwell, 1981; Salancik, 1977; Vafeas, 2003). They stated that directors' organizational commitment increases in tenure. Longer tenure executive directors may have high job satisfaction and they are less likely to give back their job acceptance. Thus, directors with extended tenure can enhance the commitment of directors to fulfill their duties and reduce their turnover. In essence, long-tenure directors possess high commitment and willingness to work better. They also possess greater experience, expertise, and reputation which are beneficial for the firm. On the other hand, long-tenured boards may lead to entrenchment which reduces the effectiveness of independent directors. Long- tenured independent directors are more likely to have a friendly relationship with the management 
(Vafeas, 2003). The reason is that their independence is very likely to be compromised as their tenures increase, as controlling shareholders possess the incentives to influence on the appointment of independent directors (Anderson, Mansi, \& Reeb, 2004). This particularly applies to firms operating in emerging markets because such kind of firms possess high levels of ownership concentration and are mostly family-controlled (Claessens et.al, 2000; Morck \& Yeung, 2003). Studies such as Bebchuk, Fried, \& Walker (2002) Bebchuk and Fried (2003) suggest that management may also use their power to influence the nomination process of directors. Independent directors with strong personal ties are more likely to reappoint and survive for the long term. These directors will not operate independently because they already have strong personal ties with the management (Canavan, Jones, \& Potter, 2004). In addition, long-tenured directors are less mobile and less employable (Vafeas, 2003). As business operations become more sophisticated and change frequently, long-tenured directors increasingly find it difficult to keep up with technology changes and advances, financial dealings, and business strategies as compared with their new counterparts. Furthermore, the former also lack talent to deal with new issues (Canavan et.al, 2004). Moreover, it can be argued that the entrenchment effects of long-tenured board could be higher in family firms compared to non-family firms in the Malaysian capital markets because family controlling shareholders have the incentives to exert more influence over independent directors due to their interest in managing the firm in their own way to fulfill their private objectives at the expense of the minority shareholders (Anderson \& Reeb, 2003). Considering the existing literature on long-tenured directors as well as the context in which they operate which is the emerging market context with poorer protection of investors' rights and regulatory environment as compared with developed markets, it is likely that longtenured directors are not beneficial for Malaysian family firms.

\section{Research Hypotheses}

Motivated by previous research, this study investigates the following research hypotheses:

$\mathbf{H}_{\mathbf{0 1}}$ : There is a negative relationship between independent directors' tenure and firm value among Malaysian firms.

$\mathbf{H}_{\mathbf{0 2}}$ : The negative relationship between independent directors' tenure and firm value among Malaysian firms will be stronger for family than for non-family firms.

The moderating role of ownership concentration on expropriation is important to be examined particularly in emerging markets due to the higher level of ownership concentration of in such markets (Claessens et al., 2000; Morck \& Yeung, 2003). In the context of the emerging markets, particularly in Asia, it is argued that there is a positive relationship between ownership concentration and firm value (Heugens, Essen, \& Oosterhout, 2009). In institutional setting of emerging markets, investors have no choice but to accept and play their role as firm monitors that they can exercise effectively only through concentrating their equity holdings. Concentrated ownership provides them powerful incentives to be involved in governance as well as a means to influence managers through direct access trading strategies and influence of their concentrated voting rights (David, Hitt, \& Liang, 2007). Consequently, controlling shareholders can stimulate or even coerce the corporate leadership to work in their interest (Heugens et al., 2009). Hence, increased 
ownership concentration may possibly allow controlling shareholders to increase their corporate control. Thus, reducing agency problem type I, i.e., the conflict between controlling shareholders and managers. This induces a positive relationship between ownership concentration and firm value. In addition, in the context of the Malaysian institutional setting and corporate governance environment, it is further argued that after the Transmile case reputational concerns possibly play a prominent role in influencing a positive moderating effect of family controlling shareholders' ownership on expropriation. These reputational effects are particularly prevalent in family owners in large family firms who usually hold high equity stakes. These family owners would like to improve their reputation after the Transmile case because Transmile is a large family-owned corporation in Malaysia. Large family firms would like to see that their reputation improved because poor corporates' reputation can affect them and their family members (Gomez, 1999; Loy, 2010). As shareholding of family owners increases, they confront with higher ownership stakes of their firms. Consequently, they have higher incentives to take care of their reputation by reducing minority shareholder expropriation. Thus, increased ownership helps align the incentives of family owners to those of minority shareholders due to the most reputational effects (Loy, 2010). In other words, reputational effects help align the respective incentives of family firms to those of minority shareholders and this reduces agency problem type II, i.e., the conflict between controlling and minority shareholders. Ultimately, this stimulates a positive moderating effect of controlling shareholders' ownership on firm value. Based on the above arguments, it is hypothesized that controlling shareholders' ownership is likely to positively moderate the firm value effects of independent directors' tenure in this research. Hence, the following hypotheses are developed:

$\mathbf{H}_{0_{3}}$ : There is a positive moderating effect of the controlling shareholders' ownership concentration on the relationship between independent directors' tenure and firm value among Malaysian firms.

$\mathbf{H}_{\mathbf{0 4}}$ : The positive moderating effect of the controlling shareholder's ownership concentration on the relationship between independent directors' tenure and firm value among Malaysian firms is stronger for family than non-family firms.

\section{Method}

The secondary type of data related to the existence of different types of ultimate owner, financial information, and board statistics for the period 2007-2009. This is a period of global financial crisis (Mishkin, 2013). These periods are chosen because of corporate governance matters during the financial crisis (Johnson, Porta, Lopez-de-Silanes, \& Shleifer, 2000). In addition, the period of 2007-2009 is chosen in order to take into consideration the reputational effects of family firms after the Transmile case in 2006 which could affect the research results. The data is obtained from companies' annual financial reports or from Bloomberg database. 
Table 1

Description of Data Set Selected for Family Firms

\begin{tabular}{l} 
Data Description \\
\hline Total Main Market Family Firms: Listed on Bursa Malaysia which Could be Utilized in the Research, as at 31st \\
December, 2007 \\
Minus: Financial Related Family Firms \\
Minus: Family Firms with Missing Data \\
Minus: Family Firms with at least 20 Per cent Family Ownership but no Family Members Involved in Management \\
Minus: Family Firms with Less than 20 Per cent Family Ownership \\
Number of Family Firms Available for Observation
\end{tabular}

In this study, family firms are defined as firms which are controlled by individuals or families with at least 20 per cent of the voting rights (Chakrabarty, 2009) as well as family involvement in the management of their firms. For this purpose, this requires at least one family member such as board member, CEO or chairman, chairman of the syndicate pact which holds a managerial position (Cascino et al., 2010). Table 2 shows the description of data set which selected the from non-family firms from 2007 to 2009 .

Table 2

Description of Data Set Selected from the Non-Family Firms from 2007 to 2009

\begin{tabular}{lc}
\hline Data Description & Number of Companies \\
\hline Total Main Market Non-Family Firms Listed on Bursa Malaysia and could be Utilized in the Research at & 223 \\
$31^{\text {st }}$ December, 2007 & 24 \\
Minus : Financial Related to Non-Family Firms & 6 \\
Minus : Non-Family Firms with Missing Data & 42 \\
Minus : Non-Family Firms with less than 20 Per cent Ownership by Controlling Shareholders & 151 \\
Number of Non-Family Firms Available for Observation & \\
\hline
\end{tabular}

Table 3 shows all the proxies which are used to measure the dependent variables in this study.

Table 3

Dependent Variables \& Measurement

\begin{tabular}{|c|c|c|}
\hline No. & $\begin{array}{c}\text { Dependent } \\
\text { Variable }\end{array}$ & Measurement \\
\hline 1 & $\begin{array}{c}\text { Firm Value } \\
\text { (Proxy 1) }\end{array}$ & $\begin{array}{l}\text { Tobin's Q is measured by using the following ratio: (Total Market Value of Equity }+ \text { Total Book Value of } \\
\text { Liabilities) / (Total Book Value of Equity + Total Book Value of Liabilities) (Anderson \& Reeb, 2003; Faccio et } \\
\text { al., 2001; Yermack, 1996). }\end{array}$ \\
\hline 2 & $\begin{array}{l}\text { Firm Value } \\
\text { (Proxy 2) }\end{array}$ & $\begin{array}{l}\text { As an alternative measure to firm value, the market to book value (MBV) is also used. MBV is calculated using } \\
\text { the following ratio: (The number of equity shares x the closing price of the stock on the last day of the financial } \\
\text { year) / Total Book Value of Equity (Reddy, Locke, \& Scrimgeour, 2010; J. Sarkar \& S. Sarkar, 2000). MBV is } \\
\text { empirically a cleaner measure than Tobin's Q and has been utilized as an alternative to it for emerging market } \\
\text { studies (Xu \& Wang, 1997) in China as well in other studies (Capon, Farley, \& Hoening., 1996). This measure } \\
\text { is also more aligned to shareholders' objectives (J. Sarkar \& S. Sarkar, 2000). }\end{array}$ \\
\hline 3 & $\begin{array}{l}\text { Return on } \\
\text { Equity (ROE) } \\
\text { (Proxy } 3 \text { ) }\end{array}$ & $\begin{array}{l}\text { Return on Equity (ROE) is used as part of the accounting-based performance measures for this kind of study } \\
\text { (Ibrahim 2009). ROE is measured as follows: Net Income / Total Common Equity (Holderness \& Sheehan, } \\
\text { 1988). }\end{array}$ \\
\hline 4 & $\begin{array}{l}\text { Return on } \\
\text { Asset (ROA) } \\
\text { (Proxy } 4)\end{array}$ & $\begin{array}{l}\text { Return on Asset (ROA) is used as part of the accounting-based performance measures for this kind of study } \\
\text { (Ibrahim, 2009). ROA is measured as follows: Net Income / Total Assets (Anderson \& Reeb, 2003; Holderness } \\
\text { \& Sheehan, 1988). }\end{array}$ \\
\hline
\end{tabular}


Table 4 explains the independent variables used in this study.

Table 4

Independent \& Dependent Variables of Measurement

\begin{tabular}{|c|c|c|}
\hline Variables & & Description \\
\hline & Directors' Tenure & $\begin{array}{l}\text { The tenure of independent directors is measured by adding up the tenure of each independent } \\
\text { director of the firm (each tenure is measured from the year he or she was appointed as an } \\
\text { independent director until the year of the annual report being analyzed) and divided by the } \\
\text { number of independent directors in order to obtain the average value. This measurement } \\
\text { indirectly indicates the likelihood of independent directors being influenced by controlling } \\
\text { shareholders and therefore, no longer 'truly' independent. This measurement is used in } \\
\text { board independence studies (Abdelsalam \& El-Masry, 2008; Vafeas, 2003). }\end{array}$ \\
\hline Independent & Ownership & $\begin{array}{l}\text { This is extracted from the data of the substantial shareholding in the annual report. It is } \\
\text { measured in terms of percentage of total equity held by each controlling shareholder } \\
\text { (Demsetz \& Lehn, 1985; Gul, Kim, \& Qiu, 2010). In the context of Malaysian annual } \\
\text { reports, the substantial shareholding (i.e. the highest shareholding in the firm held by a } \\
\text { shareholder) is calculated by summating the direct and indirect shareholding of that } \\
\text { shareholder. These direct and indirect shareholding do cover (if any) shareholding via nominees } \\
\text { or nominee companies as well as holding companies. There are notes in the annual reports } \\
\text { stating who this substantial shareholder is through the direct shareholding as well as how this } \\
\text { substantial shareholder is related to his or her indirect shareholding (if any). }\end{array}$ \\
\hline Control & $\begin{array}{l}\text { Concentration } \\
(\mathrm{OC})\end{array}$ & $\begin{array}{l}\text { In line with prior corporate governance literature, we control for twelve variables, namely } \\
\text { firm size (SIZE), firm risk (RISK), leverage (LEV), and proportion of independent directors } \\
\text { (IDR), firm age (AGE), non-affiliated block holders (NAB), sales growth (SG), R \& D } \\
\text { expenditure-to-sales (RDS), capital expenditure-to-sales (CS), marketing and advertising } \\
\text { expenditure-to-sales (MS), and gross domestic product (GDP). }\end{array}$ \\
\hline
\end{tabular}

For hypotheses testing, panel data analysis using the Pooled Ordinary Least Square (OLS) Regression Model and the Fixed Effects Model (FEM) were used. For panel data studies with large number of firms during small number of time periods, i.e., 3 years in this research, it is usual to use a pooled OLS regression model (Baltagi, Bresson, \& Pirotte, 2008). According to Kunst (2009), the F-test can be used to assess for pool-ability of the data. The results of the F-test for the panel data showed that significant quantities of F- statistics in the regression analyses are statistically significant. The significant quantities of statistical significance show that the data can be pooled because the data was sufficiently heterogeneous and hence, the used pooled OLS model in this research is considered to be valid. Subsequently, the Random Effects Model (REM) was run to compare with the pooled OLS model. Unfortunately, the Correlated Random Effects model and Hausman Test showed that the Random Effects Model (REM) is not appropriate to be used because the random effects are correlated with other repressors. Hence, the Fixed Effects Model (FEM) was used instead of the Random Effects Model (REM). The model utilized the instrumental variable (IV) regression method which did not allow for non-linearity in order to maintain the model parsimony (Gujarati \& Porter, 2009). The panel data regression model is conducted on family firms, non-family firms, and the pooled model. The family firm model of this research is as follows:

1. $\mathrm{Q}_{\mathrm{it}}=\beta_{0}+\beta_{1}(\text { Tenure })_{\mathrm{it}}+\beta_{2}(\mathrm{OC})_{\mathrm{it}}+\beta_{3}(\mathrm{SIZE})_{\mathrm{it}}+\beta_{4}(\mathrm{RISK})_{\mathrm{it}}+\beta_{5}(\mathrm{LEV})_{\mathrm{it}}+\beta_{6}(\mathrm{IDR})_{\mathrm{it}}+\beta_{7}(\mathrm{NAB})_{\mathrm{it}}+$ $\beta_{8}(\mathrm{AGE})_{\mathrm{it}}+\beta_{9}(\mathrm{SG})_{\mathrm{it}}+\beta_{10}(\mathrm{RDS})_{\mathrm{it}}+\beta_{11}(\mathrm{CS})_{\mathrm{it}}+\beta_{12}(\mathrm{MS})_{\mathrm{it}}+\beta_{13}(\mathrm{GDP})_{\mathrm{it}}+\beta_{14}(\mathrm{OC})_{\mathrm{it}}(\text { Tenure })_{\mathrm{it}}+\mu_{\mathrm{it}}$

2. $\mathrm{MBV}_{\mathrm{it}}=\beta_{0}+\beta_{1}(\text { Tenure })_{\mathrm{it}}+\beta_{2}(\mathrm{OC})_{\mathrm{it}}+\beta_{3}(\mathrm{SIZE})_{\mathrm{it}}+\beta_{4}(\mathrm{RISK})_{\mathrm{it}}+\beta_{10}(\mathrm{RDS})_{\mathrm{it}}+\beta_{11}(\mathrm{CS})_{\mathrm{it}}+\beta_{12}(\mathrm{MS})_{\mathrm{it}}+$ $\beta_{13}(\mathrm{GDP})_{\mathrm{it}}+\beta_{14}(\mathrm{OC})_{\mathrm{it}}(\text { Tenure })_{\mathrm{it}}+\mu_{\mathrm{it}}$

3. $\operatorname{ROE}_{\mathrm{it}}=\beta_{0}+\beta_{1}(\text { Tenure })_{\mathrm{it}}+\beta_{2}(\mathrm{OC})_{\mathrm{it}}+\beta_{3}(\mathrm{SIZE})_{\mathrm{it}}+\beta_{4}(\mathrm{RISK})_{\mathrm{it}}+\beta_{5}(\mathrm{LEV})_{\mathrm{it}}+\beta_{6}(\mathrm{IDR})_{\mathrm{it}}+\beta_{7}(\mathrm{NAB})_{\mathrm{it}}+$ 


$$
\beta_{8}(\mathrm{AGE})_{\mathrm{it}}+\beta_{9}(\mathrm{SG})_{\mathrm{it}}+\beta_{10}(\mathrm{RDS})_{\mathrm{it}}+\beta_{11}(\mathrm{CS})_{\mathrm{it}}+\beta_{12}(\mathrm{MS})_{\mathrm{it}}+\beta_{13}(\mathrm{GDP})_{\mathrm{it}}+\beta_{14}(\mathrm{OC})_{\mathrm{it}}(\text { Tenure })_{\mathrm{it}}+\mu_{\mathrm{it}}
$$

4. ROA $_{\mathrm{it}}=\beta_{0}+\beta_{1}(\text { Tenure })_{\mathrm{it}}+\beta_{2}(\mathrm{OC})_{\mathrm{it}}+\beta_{3}(\mathrm{SIZE})_{\mathrm{it}}+\beta_{4}(\mathrm{RISK})_{\mathrm{it}}+\beta_{5}(\mathrm{LEV})_{\mathrm{it}}+\beta_{6}(\mathrm{IDR})_{\mathrm{it}}+\beta_{7}(\mathrm{NAB})_{\mathrm{it}}$ $+\beta_{8}(\mathrm{AGE})_{\mathrm{it}}+\beta_{9}(\mathrm{SG})_{\mathrm{it}}+\beta_{10}(\mathrm{RDS})_{\mathrm{it}}+\beta_{11}(\mathrm{CS})_{\mathrm{it}}+\beta_{12}(\mathrm{MS})_{\mathrm{it}}+\beta_{13}(\mathrm{GDP})_{\mathrm{it}}+\beta_{14}(\mathrm{OC})_{\mathrm{it}}(\text { Tenure })_{\mathrm{it}}+\mu_{\mathrm{it}}$

The pooled model for the performance of both family and non-family firms is as follows:

1. $\mathrm{Q}_{\mathrm{it}}=\beta_{0}+\beta_{1}(\text { Tenure })_{\mathrm{it}}+\beta_{2}(\mathrm{OC})_{\mathrm{it}}+\beta_{3}(\mathrm{SIZE})_{\mathrm{it}}+\beta_{4}(\mathrm{RISK})_{\mathrm{it}}+\beta_{5}(\mathrm{LEV})_{\mathrm{it}}+\beta_{6}(\mathrm{IDR})_{\mathrm{it}}+\beta_{7}(\mathrm{NAB})_{\mathrm{it}}+$ $\beta_{8}(\mathrm{AGE})_{\mathrm{it}}+\beta_{9}(\mathrm{SG})_{\mathrm{it}}+\beta_{10}(\mathrm{RDS})_{\mathrm{it}}+\beta_{11}\left(\mathrm{CS}_{\mathrm{it}}+\beta_{12}(\mathrm{MS})_{\mathrm{it}}+\beta_{13}(\mathrm{GDP})_{\mathrm{it}}+\beta_{14}(\mathrm{OC})_{\mathrm{it}}(\mathrm{Tenure})_{\mathrm{it}}+\beta_{15} \mathrm{FT}_{\mathrm{it}}+\mu_{\mathrm{it}}\right.$

2. $\mathrm{MBV}_{\mathrm{it}}=\beta_{0}+\beta_{1}(\text { Tenure })_{\mathrm{it}}+\beta_{2}(\mathrm{OC})_{\mathrm{it}}+\beta_{3}(\mathrm{SIZE})_{\mathrm{it}}+\beta_{4}(\mathrm{RISK})_{\mathrm{it}}+\beta_{10}(\mathrm{RDS})_{\mathrm{it}}+\beta_{11}(\mathrm{CS})_{\mathrm{it}}+\beta_{12}(\mathrm{MS})_{\mathrm{it}}+$ $\beta_{13}(\mathrm{GDP})_{\mathrm{it}}+\beta_{14}(\mathrm{OC})_{\mathrm{it}}(\text { Tenure })_{\mathrm{it}}+\beta_{15} \mathrm{FT}_{\mathrm{it}}+\mu_{\mathrm{it}}$

3. $\operatorname{ROE}_{\mathrm{it}}=\beta_{0}+\beta_{1}(\text { Tenure })_{\mathrm{it}}+\beta_{2}(\mathrm{OC})_{\mathrm{it}}+\beta_{3}(\mathrm{SIZE})_{\mathrm{it}}+\beta_{4}(\mathrm{RISK})_{\mathrm{it}}+\beta_{5}(\mathrm{LEV})_{\mathrm{it}}+\beta_{6}(\mathrm{IDR})_{\mathrm{it}}+\beta_{7}(\mathrm{NAB})_{\mathrm{it}}+$ $\beta_{8}(\mathrm{AGE})_{\mathrm{it}}+\beta_{9}(\mathrm{SG})_{\mathrm{it}}+\beta_{10}(\mathrm{RDS})_{\mathrm{it}}+\beta_{11}(\mathrm{CS})_{\mathrm{it}}+\beta_{12}(\mathrm{MS})_{\mathrm{it}}+\beta_{13}(\mathrm{GDP})_{\mathrm{it}}+\beta_{14}(\mathrm{OC})_{\mathrm{it}}(\text { Tenure })_{\mathrm{it}}+\beta_{15} \mathrm{FT}_{\mathrm{it}}+\mu_{\mathrm{it}}$

4. $\mathrm{ROA}_{\mathrm{it}}=\beta_{0}+\beta_{1}(\text { Tenure })_{\mathrm{it}}+\beta_{2}(\mathrm{OC})_{\mathrm{it}}+\beta_{3}(\mathrm{SIZE})_{\mathrm{it}}+\beta_{4}(\mathrm{RISK})_{\mathrm{it}}+\beta_{5}(\mathrm{LEV})_{\mathrm{it}}+\beta_{6}(\mathrm{IDR})_{\mathrm{it}}+\beta_{7}(\mathrm{NAB})_{\mathrm{it}}+$ $\beta_{8}(\mathrm{AGE})_{\mathrm{it}}+\beta_{9}(\mathrm{SG})_{\mathrm{it}}+\beta_{10}(\mathrm{RDS})_{\mathrm{it}}+\beta_{11}(\mathrm{CS})_{\mathrm{it}}+\beta_{12}(\mathrm{MS})_{\mathrm{it}}+\beta_{13}(\mathrm{GDP})_{\mathrm{it}}+\beta_{14}(\mathrm{OC})_{\mathrm{it}}(\text { Tenure })_{\mathrm{it}}+\beta_{15} \mathrm{FT}_{\mathrm{it}}+\mu_{\mathrm{it}}$

In these models $\mathrm{Q}_{\mathrm{it}}, \mathrm{MBV}_{\mathrm{it}}, \mathrm{ROA}_{\mathrm{it}}$, and $\mathrm{OC}_{\mathrm{it}}$ stand for performance measured by Tobin's $\mathrm{Q}$ in year $t$, performance measured by book-to-market value ratio in year $t$, performance measured by Return on Equity in year $t$, performance measured by return on asset in year $t$, respectively. Also, tenure ${ }_{i t}$ refers to the average tenure of independent directors in the firm in year $\mathrm{t} . \mathrm{OC}_{\mathrm{it}}$ also stands for controlling shareholders' ownership concentration in the firm in year t. Finally, (OC) it $(\text { Tenure })_{\text {it }}$ refers to controlling shareholders' ownership concentration in the firm in year $t$ multiplied by average tenure of independent directors in the firm during year $t$. Furthermore, the control variables of this study included SIZE $_{i t}$, RISK $_{i t}, \mathrm{LEV}_{\mathrm{it}}, \mathrm{IDR}_{\mathrm{it}}, \mathrm{NAB}_{\mathrm{it}}, \mathrm{AGE}_{\mathrm{it}}, \mathrm{SG}_{\mathrm{it}}$, $\mathrm{RDS}_{\mathrm{it}}, \mathrm{CS}_{\mathrm{it}}, \mathrm{MS}_{\mathrm{it}}, \mathrm{GDP}_{\mathrm{it}}, \mathrm{FT}_{\mathrm{it}}$, and $\mu_{\mathrm{it}} . \mathrm{SIZE}_{\mathrm{it}}, \mathrm{RISK}_{\mathrm{it}}, \mathrm{LEV}_{\mathrm{it}}, \mathrm{IDR}_{\mathrm{it}}, \mathrm{NAB}_{\mathrm{it}}, \mathrm{AGE}_{\mathrm{it}}$, and $\mathrm{SG}_{\mathrm{it}}$ respectively stand for firm size in year $\mathrm{t}$ (Ln (Total Assets)), firm risk in year $\mathrm{t}$ (Firm Risk (Standard Deviation of monthly stock returns from 2007-2009)), Ln in year $t$ (Leverage (Long-term Debt/Total Assets)), independent directors ratio in year $t$ (Number of independent directors/Board Size), non-affiliated block holder shareholding in year $t$, $\mathrm{Ln}$ in year $\mathrm{t}(\mathrm{Age})$, and sales growth in year t. Other control variables were $\mathrm{RDS}_{\mathrm{it}}, \mathrm{CS}_{\mathrm{it}}, \mathrm{MS}_{\mathrm{it}}, \mathrm{GDP}_{\mathrm{it}}$, $\mathrm{FT}_{\mathrm{it}}$, and $\mu_{\mathrm{it}}$ which referred to research and development expenditure-to-sales in year t, capital expenditure-to-sales in year $t$, marketing and advertising expenditure-to-sales in year $t$, gross domestic product in year t, firm type dummy variable in year $t$ ( 1 for family firms and 0 for non- family firms), and stochastic error term in year $\mathrm{t}$.

\section{Results}

Table 5 and 6 present the summary statistics for the continuous variables of the family and non-family firms. They show that the average tenure of independent directors. 
Table 5

Descriptive Statistics for Family Firms

\begin{tabular}{lccccc}
\hline & Mean & Median & SD & Max. & Min. \\
\hline Tobin's Q & 0.87 & 0.78 & 0.52 & 7.03 & 0.06 \\
ROE & 0.03 & 0.06 & 0.30 & 3.00 & -5.34 \\
ROA & 0.03 & 0.03 & 0.08 & 0.41 & -0.64 \\
Market-to- Book Value (MBV) & 0.80 & 0.58 & 1.06 & 16.29 & -0.39 \\
Average Independent Directors' Tenure & 6.03 & 5.33 & 3.86 & 31.00 & 0.00 \\
Ownership Concentration & 42.14 & 41.18 & 13.31 & 99.16 & 20.18 \\
Predicted Ownership Concentration & 42.06 & 42.53 & 1.57 & 44.05 & 34.41 \\
Firm Size & 19.63 & 19.49 & 1.20 & 24.49 & 16.94 \\
Ln(Firm Risk) & -2.28 & -2.33 & 0.97 & 1.25 & -5.34 \\
Leverage & 0.13 & 0.08 & 0.18 & 2.79 & 0.00 \\
Independent Directors Ratio & 0.42 & 0.40 & 0.11 & 0.83 & 0.18 \\
Non-affiliated Block holders & 27.25 & 14.76 & 38.96 & 339.26 & 0.00 \\
Ln (Age) & 2.96 & 3.09 & 0.72 & 4.63 & 0.00 \\
Sales Growth & 14.42 & 6.45 & 93.27 & 2254.70 & -96.87 \\
R \& D Expenditure to sales & 0.14 & 0.00 & 1.81 & 35.68 & 0.00 \\
Capital Expenditure to Sales & 9.28 & 3.63 & 27.20 & 561.40 & -37.05 \\
Marketing and Advertising Expenditure to Sales & 2.30 & 0.40 & 4.09 & 62.06 & 0.00 \\
Gross Domestic Product & 3.21 & 4.80 & 3.50 & 6.48 & -1.63
\end{tabular}

Table 6

Descriptive Statistics for Non-Family Firms

\begin{tabular}{|c|c|c|c|c|c|}
\hline & Mean & Median & SD & Max. & Min. \\
\hline Tobin's Q & 1.15 & 0.88 & 1.08 & 11.33 & 0.25 \\
\hline ROE & 0.05 & 0.08 & 1.04 & 2.52 & -20.76 \\
\hline ROA & 0.06 & 0.05 & 0.55 & 11.05 & -1.88 \\
\hline Market-to- Book Value (MBV) & 1.32 & 0.74 & 2.79 & 34.87 & -2.40 \\
\hline Average Independent Directors' Tenure & 5.52 & 4.79 & 4.47 & 17.25 & 0.12 \\
\hline Ownership Concentration & 46.07 & 48.41 & 15.95 & 89.62 & 2.10 \\
\hline Predicted Ownership Concentration & 43.32 & 43.97 & 16.56 & 49.53 & 26.47 \\
\hline Firm Size & 20.14 & 19.88 & 1.40 & 24.99 & 16.30 \\
\hline Ln (Firm Risk) & 0.28 & 0.16 & 0.36 & 2.74 & 0.00 \\
\hline Leverage & 0.12 & 0.07 & 0.14 & 0.69 & 0.00 \\
\hline Independent Directors Ratio & 0.42 & 0.40 & 0.11 & 0.83 & 0.14 \\
\hline Non-affiliated Block holders & 55.27 & 24.56 & 82.96 & 517.63 & 0.00 \\
\hline Ln (Age) & 24.58 & 21.00 & 16.48 & 118.00 & 1.00 \\
\hline Sales Growth & 7.10 & 4.80 & 43.78 & 418.11 & -87.12 \\
\hline R \& D Expenditure- to-Sales & 0.08 & 0.00 & 0.45 & 5.96 & 0.00 \\
\hline Capital Expenditure- to-Sales & 7.76 & 3.42 & 15.12 & 207.96 & 0.00 \\
\hline Marketing and Advertising Expenditure- to-Sales & 3.37 & 0.00 & 7.12 & 59.19 & 0.00 \\
\hline Gross Domestic Product & 3.21 & 4.80 & 3.50 & 6.48 & -1.63 \\
\hline
\end{tabular}

Table 7 presents the t-test results for testing the differences between the variables in family firms and non- family firms. On average, there was no significant difference between family and non-family firms because the t-test results indicated the probability of 0.98 which is statistically insignificant at 1 per cent, 5 per cent, and 10 per cent of significance level, respectively. This is inconsistent with the findings of Dieleman (2012) and Schulze, Lubatkin, and Dino (2003) who found that family firms have significantly longer tenures of independent directors compared to non-family firms. The results also suggested a higher level of interlocking directorship (cross-directorship) between independent directors in family and non-family firms which result in insignificant differences. 
Table 7

T-Test Results (2-tailed) to Compare the Variable Values of Family Firms \& Non-Family Firms

\begin{tabular}{lc}
\hline Variables & Probability of T-Test \\
\hline Tobin's Q & $2.01 \times 10^{-7} * * *$ \\
ROE & 0.71 \\
ROA & 0.15 \\
Market-to-Book Value (MBV) & $0.00^{* * *}$ \\
Average Independent Directors' Tenure & 0.98 \\
Ownership Concentration & $4.12 \times 10^{-6_{* * *}}$ \\
Predicted Ownership Concentration & $4.22 \times 10^{-43_{* * *}}$ \\
Firm Size & $1.7 \times 10^{-11_{* * *}}$ \\
Ln (Firm Risk) & $6.31 \times 10^{-21_{* * *}}$ \\
Leverage & 0.43 \\
Independent Directors Ratio & 0.49 \\
Non-Affiliated Block Holders & $1.54 \times 10^{-11_{* * *}}$ \\
Ln(Age) & 0.79 \\
Sales Growth & $0.03^{* *}$ \\
R \& D Expenditure-to-Sales & 0.26 \\
Capital Expenditure-to-Sales & 0.15 \\
Marketing and Advertising Expenditure-to-Sales & $0.00^{* * *}$ \\
\hline
\end{tabular}

Empirical studies which emphasize on the relationship between firm value and ownership concentration potentially suffer from the problem of endogeneity due to the information advantage of controlling shareholders. This information advantage could possibly be derived from their involvement in firms' management (Andres, 2008). Due to this advantage, controlling shareholders are able to assess their firms' future prospects which enabling them to keep their shares when firm value is high and sell their shares when they are low. Therefore, there is possibility that ownership is determined by firm value (Andres, 2008). Thus, the Hausman Specification Test (Hausman, 1978) for endogeneity is performed to test whether this endogeneity exist or not. The results showed that ownership concentration is endogenously related to Return on Equity (ROE) and Return on Asset (ROA) in family firms as well as in the combined family and non-family firms. In addition, ownership concentration is endogenously related to Tobin's Q in non-family firms. To address the endogeneity issue, Gujarati and Porter (2009) used an instrumental variable to eliminate the problem of endogeneity. Since, Demsetz and Lehn (1985) argued that ownership is a function of firm size and risk, the instrumental variable used is the predicted value of ownership concentration which is obtained through regression of the original ownership concentration values against firm size, the square root of firm size, and firm risk (Himmelberg, Hubbard, \& Palia, 1999). Tables 8 and 9 show the regression results of the Pooled OLS and Fixed Effects Model for family. They depicted that the average independent directors' tenure significantly reduce firm value (MBV) at 10 per cent significance level in family firms. When ownership concentration moderated positively the relationship between average independent directors' tenure and firm value, the firm value (Tobin's Q and MBV) effects turns positive. That was significant at the 10 per cent significance level. 
Table 8

Actual Regression Results (Main Results) Normal OLS Pooled Model (Family Firms)

\begin{tabular}{clcccc}
\hline $\begin{array}{c}\text { Expected } \\
\text { Signs }\end{array}$ & Independent Variables and Intercepts & \multicolumn{3}{c}{ Dependent Variable } \\
& & \multicolumn{2}{c}{ Tobin's Q } & \multicolumn{2}{c}{ MBV } \\
& & Coeff. & T-stats & Coeff. & T-stats \\
\hline$+/-$ & Intercept & $2.26^{* * *}$ & 6.34 & $1.82^{* * *}$ & 2.72 \\
- & Average Independent Directors' Tenure & 0.00 & 0.14 & $-0.04^{* *}$ & -1.66 \\
+ & Ownership Concentration (OC) & 0.00 & 0.46 & -0.00 & -0.65 \\
$+/-$ & Firm Size (SIZE) & $-0.06^{* * *}$ & -3.41 & -0.01 & -0.49 \\
+ & Ln (Firm Risk) & $0.13^{* * *}$ & 9.16 & $0.15^{* * *}$ & 6.16 \\
$+/-$ & Leverage(LEV) & $0.89^{* * *}$ & 13.62 & 0.04 & 0.42 \\
$+/-$ & Independent Directors Ratio (IDR) & -0.20 & -1.54 & $-0.45^{*}$ & -1.87 \\
+ & Non-Affiliated Block Holders (NAB) & $-0.00^{* *}$ & -2.32 & $-0.00^{* * *}$ & -3.79 \\
+ & Ln(Age) & 0.01 & 0.32 & -0.01 & -0.25 \\
+ & Sales Growth(SG) & 0.00 & 0.54 & 0.00 & 1.49 \\
+ & R\&D Expenditure-to-Sales(RDS) & 0.00 & 0.50 & -0.00 & -0.24 \\
+ & Capital Expenditure-to-Sales (CS) & 0.00 & 0.87 & 0.00 & 1.33 \\
$+/-$ & Marketing \& Advertising Expenditure-to-Sales (MS) & 0.00 & 0.63 & 0.00 & 1.48 \\
+ +- & Gross Domestic Product (GDP) & -0.00 & -1.20 & -0.00 & -1.21 \\
- & OC x Tenure & -0.00 & -0.36 & $0.00^{*}$ & 1.69 \\
& Adjusted R-Squared (\%) & 19.41 & & 4.50 & \\
\hline
\end{tabular}

Table 9

Actual Regression Results (Main Results) Normal OLS Pooled Model (Family Firms) (Continued)

\begin{tabular}{|c|c|c|c|c|c|}
\hline \multirow{3}{*}{$\begin{array}{l}\text { Expected } \\
\text { Signs }\end{array}$} & \multirow[t]{3}{*}{ Independent Variables and Intercepts } & \multicolumn{4}{|c|}{ Dependent Variable } \\
\hline & & \multicolumn{2}{|c|}{ ROE } & \multicolumn{2}{|c|}{ ROA } \\
\hline & & Coeff. & T-stats & Coeff. & T-stats \\
\hline$+/-$ & Intercept & 0.64 & -1.34 & $-0.40^{* * *}$ & -2.71 \\
\hline- & Average Independent Directors' Tenure & -0.04 & -0.59 & 0.01 & 0.66 \\
\hline+ & Predicted Ownership Concentration (OC) & 0.00 & 0.63 & $0.00^{* *}$ & 2.08 \\
\hline$+/-$ & Firm Size (SIZE) & 0.02 & 1.84 & $0.00^{*}$ & 1.93 \\
\hline+ & Ln (Firm Risk) & 0.02 & 2.61 & $0.00^{* *}$ & 2.82 \\
\hline$+/-$ & Leverage (LEV) & 0.05 & -1.33 & $-0.05^{* *}$ & -3.97 \\
\hline$+/--$ & Independent Directors Ratio (IDR) & -0.07 & -1.01 & $-0.04^{* *}$ & -1.67 \\
\hline+ & Non-Affiliated Block Holders (NAB) & 0.00 & 0.28 & 0.00 & 1.07 \\
\hline+ & Ln(Age) & -0.01 & -1.28 & -0.00 & -1.47 \\
\hline+ & Sales Growth(SG) & 0.00 & 1.11 & $0.00^{* *}$ & 1.76 \\
\hline+ & R\&D Expenditure-to-Sales(RDS) & 0.00 & 0.04 & 0.00 & 0.46 \\
\hline+ & Capital Expenditure-to-Sales (CS) & 0.00 & -0.47 & -0.00 & -1.45 \\
\hline$+/-$ & Marketing \& Advertising Expenditure-to-Sales (MS) & 0.00 & 0.18 & -0.00 & -1.00 \\
\hline$+/-$ & Gross Domestic Product (GDP) & 0.00 & 2.98 & $0.00^{* *}$ & 2.15 \\
\hline \multirow[t]{3}{*}{-} & OC x Tenure & 0.00 & 0.71 & -0.00 & -0.53 \\
\hline & Adjusted R-Squared (\%) & 4.95 & & 7.33 & \\
\hline & F-Statistic & $5.23^{* *}$ & & $7.42^{* * *}$ & \\
\hline
\end{tabular}


Table 10

Actual Regression Results (Main Results) Normal OLS Regression Fixed Effects Model (Family Firms)

\begin{tabular}{|c|c|c|c|c|c|}
\hline \multirow{3}{*}{$\begin{array}{c}\text { Expected } \\
\text { Signs }\end{array}$} & \multirow[t]{3}{*}{ Independent Variables and Intercepts } & \multicolumn{4}{|c|}{ Dependent Variable } \\
\hline & & \multicolumn{2}{|c|}{ Tobin’s Q } & \multicolumn{2}{|c|}{ MBV } \\
\hline & & Coeff. & T-stats & Coeff. & T-stats \\
\hline$+/-$ & Intercept & $2.26^{* * *}$ & 6.39 & $1.72 * * *$ & 2.58 \\
\hline- & Average Independent Directors' Tenure & 0.00 & 0.30 & -0.03 & -1.46 \\
\hline+ & Ownership Concentration (OC) & 0.00 & 0.62 & -0.00 & -0.43 \\
\hline$+/-$ & Firm Size (SIZE) & $-0.06^{* * *}$ & -3.55 & -0.01 & -0.44 \\
\hline+ & Ln (Firm Risk) & $0.13 * * *$ & 9.12 & $0.15^{* * *}$ & 6.15 \\
\hline$+/-$ & Leverage(LEV) & $0.89 * * *$ & 13.79 & 0.03 & 0.26 \\
\hline$+/-$ & Independent Directors Ratio (IDR) & -0.16 & -1.21 & -0.35 & -1.49 \\
\hline+ & Non-Affiliated Block Holders (NAB) & $-0.00 * *$ & -2.17 & $-0.00 * * *$ & -3.67 \\
\hline+ & Ln(Age) & 0.01 & 0.53 & 0.00 & 0.04 \\
\hline+ & Sales Growth(SG) & 0.00 & 0.62 & 0.00 & 1.46 \\
\hline+ & R\&D Expenditure-to-Sales(RDS) & 0.00 & 0.42 & -0.00 & -0.33 \\
\hline+ & Capital Expenditure-to-Sales (CS) & 0.00 & 0.89 & 0.00 & 1.25 \\
\hline$+/-$ & Marketing \& Advertising Expenditure-to-Sales (MS) & 0.00 & 0.62 & 0.00 & 1.51 \\
\hline \multirow[t]{3}{*}{-} & OC $\mathrm{x}$ Tenure & -0.00 & -0.43 & 0.00 & 1.57 \\
\hline & Adjusted R-Squared (\%) & 21.87 & & 8.63 & \\
\hline & F-Statistic & $22.20^{* * *}$ & & $8.16^{* * *}$ & \\
\hline
\end{tabular}

Table 11

Actual Regression Results (Main Results) Normal OLS Regression Fixed Effects Model (Family Firms) (Continued)

\begin{tabular}{|c|c|c|c|c|c|}
\hline \multirow{3}{*}{$\begin{array}{c}\text { Expected } \\
\text { Signs }\end{array}$} & \multirow[t]{3}{*}{ Independent Variables and Intercepts } & \multicolumn{4}{|c|}{ Dependent Variable } \\
\hline & & \multicolumn{2}{|c|}{ ROE } & \multicolumn{2}{|c|}{ ROA } \\
\hline & & Coeff. & T-stats & Coeff. & T-stats \\
\hline$+/-$ & Intercept & -0.63 & -1.31 & $-0.40^{* * *}$ & -2.68 \\
\hline- & Average Independent Directors' Tenure & -0.04 & -0.58 & 0.01 & 0.65 \\
\hline+ & Predicted Ownership Concentration (OC) & 0.00 & 0.64 & $0.00^{* *}$ & 2.07 \\
\hline$+/-$ & Firm Size (SIZE) & $0.02^{* *}$ & 1.84 & $0.00^{*}$ & 1.93 \\
\hline+ & Ln (Firm Risk) & $0.02^{* * *}$ & 2.59 & $0.00^{* * *}$ & 2.83 \\
\hline$+/-$ & Leverage(LEV) & -0.05 & -1.32 & $-0.051^{* * *}$ & -3.90 \\
\hline$+/-$ & Independent Directors Ratio (IDR) & -0.08 & -1.04 & $-0.03^{*}$ & -1.65 \\
\hline+ & Non-Affiliated Block Holders (NAB) & 0.00 & 0.26 & 0.00 & 1.08 \\
\hline+ & Ln (Age) & -0.01 & -1.30 & -0.00 & -1.46 \\
\hline+ & Sales Growth(SG) & 0.00 & 1.09 & $0.00^{*}$ & 1.77 \\
\hline+ & R\&D Expenditure-to-Sales(RDS) & 0.00 & 0.05 & 0.00 & 0.46 \\
\hline+ & Capital Expenditure-to-Sales (CS) & -0.00 & -0.47 & -0.00 & -1.45 \\
\hline$+/-$ & Marketing \& Advertising Expenditure-to-Sales (MS) & 0.00 & 0.18 & -0.00 & -1.00 \\
\hline \multirow[t]{3}{*}{-} & OC $x$ Tenure & 0.00 & 0.70 & -0.00 & -0.52 \\
\hline & Adjusted R-Squared (\%) & 4.96 & & 7.26 & \\
\hline & F-Statistic & $4.95^{* * *}$ & & $6.93^{* * *}$ & \\
\hline
\end{tabular}

Tables 12 and 13 show the data related to non-family firms. There were inconclusive evidence about the significance of the association between average independent directors' tenure and firm value because there were a significant negative relationship for the marketbased measures (Tobin's Q) of firm performance at a significance level of 1 per cent and a significant positive relationship for accounting-based performance measures (ROA) also at a significance level of 1 per cent. There was also inconclusive evidence on the moderating effect of the controlling shareholders' ownership on this relationship. For market-based measures of firm performance (Tobin's Q), there was a significant positive moderating effect which was significant at 1 per cent significance level whereas for accounting-based measures 
for performance, there was a significant negative moderating effect which was also significant at 1 per cent significance level.

Table 12

Actual Regression Results (Main Results) Normal OLS Pooled Model (Non-Family Firms)

\begin{tabular}{|c|c|c|c|c|c|}
\hline \multirow{3}{*}{$\begin{array}{l}\text { Expected } \\
\text { Signs }\end{array}$} & \multirow[t]{3}{*}{ Independent Variables and Intercepts } & \multicolumn{4}{|c|}{ Dependent Variable } \\
\hline & & \multicolumn{2}{|c|}{ Tobin's Q } & \multicolumn{2}{|c|}{ MBV } \\
\hline & & Coeff. & T-stats & Coeff. & T-stats \\
\hline$+/-$ & Intercept & $4.79 * * *$ & 5.39 & 0.16 & 0.06 \\
\hline- & $\begin{array}{l}\text { Average Independent Directors' } \\
\text { Tenure }\end{array}$ & $-0.34 * * *$ & -2.78 & 0.07 & 1.07 \\
\hline+ & $\begin{array}{l}\text { Predicted Ownership } \\
\text { Concentration (OC) (For Tobin's } \\
\text { Q)/Ownership Concentration (For MBV) }\end{array}$ & $-0.06^{* * *}$ & -3.69 & 0.01 & 1.44 \\
\hline$+/-$ & Firm Size (SIZE) & N/A & N/A & 0.03 & 0.23 \\
\hline+ & Ln(Firm Risk) & $0.22 * * *$ & 4.75 & $0.22 * * *$ & 3.71 \\
\hline$+/-$ & Leverage (LEV) & 0.34 & 0.97 & $1.46 * * *$ & 2.87 \\
\hline$+/-$ & Independent Directors Ratio (IDR) & $-0.69 * *$ & -2.15 & -0.47 & -0.94 \\
\hline+ & Non-Affiliated Block Holders (NAB) & $-0.00 *$ & -1.69 & -0.00 & -1.18 \\
\hline+ & Ln (Age) & 0.04 & 0.45 & 0.14 & 0.53 \\
\hline+ & Sales Growth(SG) & -0.00 & -0.86 & -0.00 & -1.50 \\
\hline+ & R\&D Expenditure-to-Sales(RDS) & -0.04 & -0.63 & -0.01 & -0.12 \\
\hline+ & Capital Expenditure-to-Sales (CS) & -0.00 & -0.32 & -0.00 & -0.56 \\
\hline$+/-$ & $\begin{array}{l}\text { Marketing \& Advertising Expenditure- } \\
\text { to-Sales (MS) }\end{array}$ & 0.00 & 0.83 & -0.00 & -0.43 \\
\hline$+/-$ & Gross Domestic Product (GDP) & -0.00 & -0.73 & 0.00 & 0.08 \\
\hline- & OC $\mathrm{x}$ Tenure & $0.00 * * *$ & 2.88 & -0.00 & -0.74 \\
\hline & Adjusted R-Squared (\%) & 7.21 & & 3.18 & \\
\hline & F-Statistic & $3.70 * * *$ & & $2.06^{* *}$ & \\
\hline
\end{tabular}

Table 13

Actual Regression Results (Main Results) Normal OLS Pooled Model (Non-Family Firms) (Continued)

\begin{tabular}{|c|c|c|c|c|c|}
\hline \multirow{2}{*}{$\begin{array}{c}\text { Expe } \\
\text { cted } \\
\text { Signs }\end{array}$} & \multirow[t]{2}{*}{ Independent Variables and Intercepts } & \multicolumn{4}{|c|}{ Dependent Variable } \\
\hline & & Coeff. & T-stats & Coeff. & T-stats \\
\hline$+/-$ & Intercept & 0.09 & 0.23 & -0.23 & -1.26 \\
\hline- & Average Independent Directors' Tenure & 0.00 & 0.39 & $0.02 * * *$ & 3.22 \\
\hline+ & Ownership Concentration & 0.00 & 0.82 & $0.00 * * *$ & 3.73 \\
\hline$+/-$ & Firm Size (SIZE) & 0.00 & 0.12 & 0.00 & 0.91 \\
\hline+ & Ln(Firm Risk) & $0.04 *$ & 1.89 & $0.01 *$ & 1.78 \\
\hline$+/-$ & Leverage(LEV) & 0.10 & 0.59 & -0.01 & -0.27 \\
\hline$+/-$ & Independent Directors Ratio (IDR) & -0.10 & -0.60 & -0.07 & -0.99 \\
\hline+ & Non-Affiliated Block Holders (NAB) & -0.00 & -1.15 & 0.00 & 0.11 \\
\hline+ & Ln(Age) & -0.00 & -0.19 & -0.01 & -0.72 \\
\hline+ & Sales Growth(SG) & 0.00 & 0.63 & $0.00 * * *$ & 3.41 \\
\hline+ & R\&D Expenditure-to-Sales(RDS) & -0.01 & -0.26 & 0.02 & 1.53 \\
\hline+ & Capital Expenditure-to-Sales (CS) & -0.00 & -1.26 & -0.00 & -0.61 \\
\hline$+/-$ & Marketing \& Advertising Expenditure-to-Sales (MS) & 0.00 & 1.23 & 0.00 & 0.65 \\
\hline$+/-$ & Gross Domestic Product (GDP) & $-0.01 * *$ & -2.29 & 0.00 & 0.35 \\
\hline- & OC $\mathrm{x}$ Tenure & -0.00 & -0.07 & $-0.00 * * *$ & -2.77 \\
\hline & Adjusted R-Squared (\%) & 1.35 & & 6.45 & \\
\hline & F-Statistic & 1.44 & & $3.22 * * *$ & \\
\hline
\end{tabular}


Table 14

Actual Regression Results (Main Results) Normal OLS Regression Fixed Effects Model (Non-Family Firms)

\begin{tabular}{|c|c|c|c|c|c|}
\hline \multirow{3}{*}{$\begin{array}{l}\text { Expected } \\
\text { Signs }\end{array}$} & \multirow[t]{3}{*}{ Independent Variables and Intercepts } & \multicolumn{4}{|c|}{ Dependent Variable } \\
\hline & & \multicolumn{2}{|c|}{ Tobin's Q } & \multicolumn{2}{|c|}{ MBV } \\
\hline & & Coeff. & T-stats & Coeff. & T-stats \\
\hline$+/-$ & Intercept & $4.45 * * *$ & 5.12 & -0.42 & -0.15 \\
\hline - & Average Independent Directors' Tenure & $-0.31 * * *$ & -2.62 & 0.07 & 1.08 \\
\hline \multirow[t]{2}{*}{+} & Predicted Ownership & & & & \\
\hline & $\begin{array}{l}\text { Concentration (OC)(For Tobin's Q)/Ownership } \\
\text { Concentration (For MBV) }\end{array}$ & $-0.06 * * *$ & -3.43 & $0.01 *$ & 1.68 \\
\hline$+/-$ & Firm Size (SIZE) & N/A & N/A & 0.04 & 0.31 \\
\hline+ & Ln(Firm Risk) & $0.21 * * *$ & 4.90 & $0.22 * * *$ & 3.89 \\
\hline$+/-$ & Leverage(LEV) & 0.35 & 1.03 & $1.46^{* * *}$ & 2.95 \\
\hline$+/--$ & Independent Directors Ratio (IDR) & $-0.71^{* *}$ & -2.33 & -0.46 & -0.97 \\
\hline+ & Non-Affiliated Block Holders (NAB) & -0.00 & -1.61 & -0.00 & -1.05 \\
\hline+ & Ln(Age) & 0.07 & 0.80 & 0.26 & 0.92 \\
\hline+ & Sales Growth(SG) & -0.00 & -1.00 & -0.00 & -1.55 \\
\hline+ & R\&D Expenditure-to-Sales(RDS) & -0.02 & -0.38 & 0.01 & 0.17 \\
\hline+ & Capital Expenditure-to-Sales (CS) & -0.00 & -0.50 & -0.00 & -0.78 \\
\hline$+/-$ & Marketing \& Advertising Expenditure-to-Sales (MS) & 0.00 & 0.71 & -0.01 & -0.59 \\
\hline \multirow[t]{4}{*}{-} & OC $x$ Tenure & $0.00 * * *$ & 2.70 & -0.00 & -0.79 \\
\hline & $\mathrm{N}$ & 151 & & 151 & \\
\hline & Adjusted R-Squared (\%) & 10.83 & & 6.39 & \\
\hline & F-Statistic & $4.92 * * *$ & & $3.05 * *$ & \\
\hline
\end{tabular}

Table 15

Actual Regression Results (Main Results) Normal OLS Regression Fixed Effects Model (Non-Family Firms (Continued)

\begin{tabular}{|c|c|c|c|c|c|}
\hline \multirow{3}{*}{$\begin{array}{l}\text { Expected } \\
\text { Signs }\end{array}$} & \multirow[t]{3}{*}{ Independent Variables and Intercepts } & \multicolumn{4}{|c|}{ Dependent Variable } \\
\hline & & \multicolumn{2}{|c|}{ ROE } & \multicolumn{2}{|c|}{ ROA } \\
\hline & & Coeff. & T-stats & Coeff. & T-stats \\
\hline$+/-$ & Intercept & 0.04 & 0.10 & -0.20 & -1.16 \\
\hline- & $\begin{array}{l}\text { Average Independent Directors' } \\
\text { Tenure }\end{array}$ & 0.00 & 0.39 & $0.02 * * *$ & 3.32 \\
\hline+ & Ownership Concentration & 0.00 & 0.82 & $0.00 * * *$ & 3.77 \\
\hline$+/-$ & Firm Size (SIZE) & 0.00 & 0.12 & 0.00 & 1.01 \\
\hline+ & Ln(Firm Risk) & $0.04 *$ & 1.89 & $0.01 *$ & 1.74 \\
\hline$+/-$ & Leverage(LEV) & 0.10 & 0.58 & -0.02 & -0.39 \\
\hline$+/--$ & Independent Directors Ratio (IDR) & -0.10 & -0.59 & -0.06 & -0.93 \\
\hline+ & Non-Affiliated Block Holders (NAB) & -0.00 & -1.15 & 0.00 & 0.11 \\
\hline+ & Ln(Age) & -0.00 & -0.19 & -0.01 & -0.78 \\
\hline+ & Sales Growth(SG) & 0.00 & 0.63 & $0.00 * * *$ & 3.52 \\
\hline+ & R\&D Expenditure-to-Sales(RDS) & -0.01 & -0.26 & $0.02 *$ & 1.71 \\
\hline+ & Capital Expenditure-to-Sales (CS) & -0.00 & -1.26 & -0.00 & -0.63 \\
\hline$+/-$ & $\begin{array}{l}\text { Marketing \& Advertising Expenditure- } \\
\text { to-Sales (MS) }\end{array}$ & 0.00 & 1.22 & 0.00 & 0.73 \\
\hline \multirow[t]{4}{*}{-} & OC $\mathrm{x}$ Tenure & -0.00 & -0.07 & $-0.00 * * *$ & -2.84 \\
\hline & $\mathrm{N}$ & 151 & & 151 & \\
\hline & Adjusted R-Squared (\%) & 1.13 & & 7.40 & \\
\hline & F-Statistic & 1.34 & & $3.4 * * *$ & \\
\hline
\end{tabular}

Tables 16 and 17 show the results of the pooled model for analyzing the performance of the both family and non-family firms. There was no statistical significant relationship between average tenure of independent directors and firm value. Furthermore, controlling shareholders' ownership had a moderating effect on this relationship. To test the robustness of the results, industry effects in this research are controlled by excluding industries which 
contain only family or non-family firms. Industries which contain only family or non-family firms are called family firms or non-family firms in exclusive industries, respectively (Anderson \& Reeb, 2003). If industry effects are not controlled, they can cause bias in the regression coefficient results because they may have a direct impact towards the firm value (Porter, 1980). The main research results which were the effects of average tenure of independent directors on firm value and the moderating effect of ownership concentration on this relationship were considered as robust against industry effects only for non-family firms. To test the robustness of family firms for family firms, average tenure of independent directors had no significant relationship with firm value. The moderating effect of controlling shareholders' ownership on this relationship was not significant. For the pooled model of family and non-family firms, there also was inconclusive evidence with regards to the relationship between average tenure of independent directors and firm value. Average tenure of independent directors reduces firm value of market-based measures of performance (Tobin's Q) and that was statistically significant at a significance level of 5 per cent whereas it increases firm value for accounting-based measures of firm performance such as ROE which was statistically significant at 5 per cent level. Similarly, for the pooled model of both family and non-family firms, there was inconclusive evidence with regards to the moderating effect of controlling shareholders' ownership on the relationship between average independent directors' tenure and firm value. Controlling shareholders' ownership had a significant positive moderating effect on this relationship for market-based measures of firm performance (Tobin's Q) which was statistically significant at 5 per cent and 10 per cent level, respectively while controlling shareholders' ownership had a significant negative moderating effect on the relationship of accounting-based measures of firm performance (ROE) and that was statistically significant at 10 per cent level.

Table 16

Actual Regression Results (Main Results) Normal OLS Pooled Model (Family Firms \& Non-Family Firms)

\begin{tabular}{|c|c|c|c|c|c|}
\hline \multirow{3}{*}{$\begin{array}{c}\text { Expected } \\
\text { Signs }\end{array}$} & \multirow[t]{3}{*}{ Independent Variables and Intercepts } & \multicolumn{4}{|c|}{ Dependent Variable } \\
\hline & & \multicolumn{2}{|c|}{ Tobin's Q } & \multicolumn{2}{|c|}{ MBV } \\
\hline & & Coeff. & T-stats & Coeff. & T-stats \\
\hline$+/-$ & Intercept & $3.28^{* * *}$ & 7.36 & $1.66^{*}$ & 1.85 \\
\hline - & Average Independent Directors' Tenure & -0.02 & -1.49 & 0.01 & 0.37 \\
\hline+ & Ownership Concentration (OC) & -0.00 & -0.81 & $0.00 * *$ & 1.99 \\
\hline$+/-$ & Firm Size (SIZE) & $-0.08 * * *$ & -4.14 & -0.01 & -0.32 \\
\hline+ & Ln(Firm Risk) & $0.14 * * *$ & 8.25 & $0.15^{* * *}$ & 6.20 \\
\hline$+/-$ & Leverage (LEV) & $0.83 * * *$ & 9.89 & 0.19 & 1.53 \\
\hline$+/-$ & Independent Directors Ratio (IDR) & $-0.39 * * *$ & -2.63 & -0.37 & -1.52 \\
\hline+ & Non-Affiliated Block Holders (NAB) & $0.02^{* * *}$ & 0.62 & $0.01 * * *$ & 0.12 \\
\hline+ & Ln (Age) & -0.00 & -2.95 & -0.00 & -3.24 \\
\hline+ & Sales Growth(SG) & 0.00 & 0.19 & 0.00 & 0.48 \\
\hline+ & R\&D Expenditure-to-Sales (RDS) & -0.00 & -0.06 & -0.01 & -0.54 \\
\hline+ & Capital Expenditure-to-Sales (CS) & -0.00 & -0.09 & 0.00 & 0.32 \\
\hline$+/-$ & Marketing \& Advertising Expenditure-to-Sales (MS) & 0.00 & 0.47 & 0.00 & 0.28 \\
\hline$+/-$ & Gross Domestic Product (GDP) & -0.00 & -0.89 & -0.00 & -0.91 \\
\hline \multirow[t]{5}{*}{ - } & OC $x$ Tenure & 0.00 & 1.50 & -0.00 & -0.38 \\
\hline & Firm Type & $-0.25 * * *$ & -4.24 & $-0.51 * * *$ & -3.52 \\
\hline & $\mathrm{N}$ & 530 & & 530 & \\
\hline & Adjusted R-Squared (\%) & 10.56 & & 3.94 & \\
\hline & F-Statistic & $13.51^{* * *}$ & & $5.35 * * *$ & \\
\hline
\end{tabular}


Table 17

Actual Regression Results (Main Results) Normal OLS Pooled Model (Family Firms \& Non-Family Frims) (Continued)

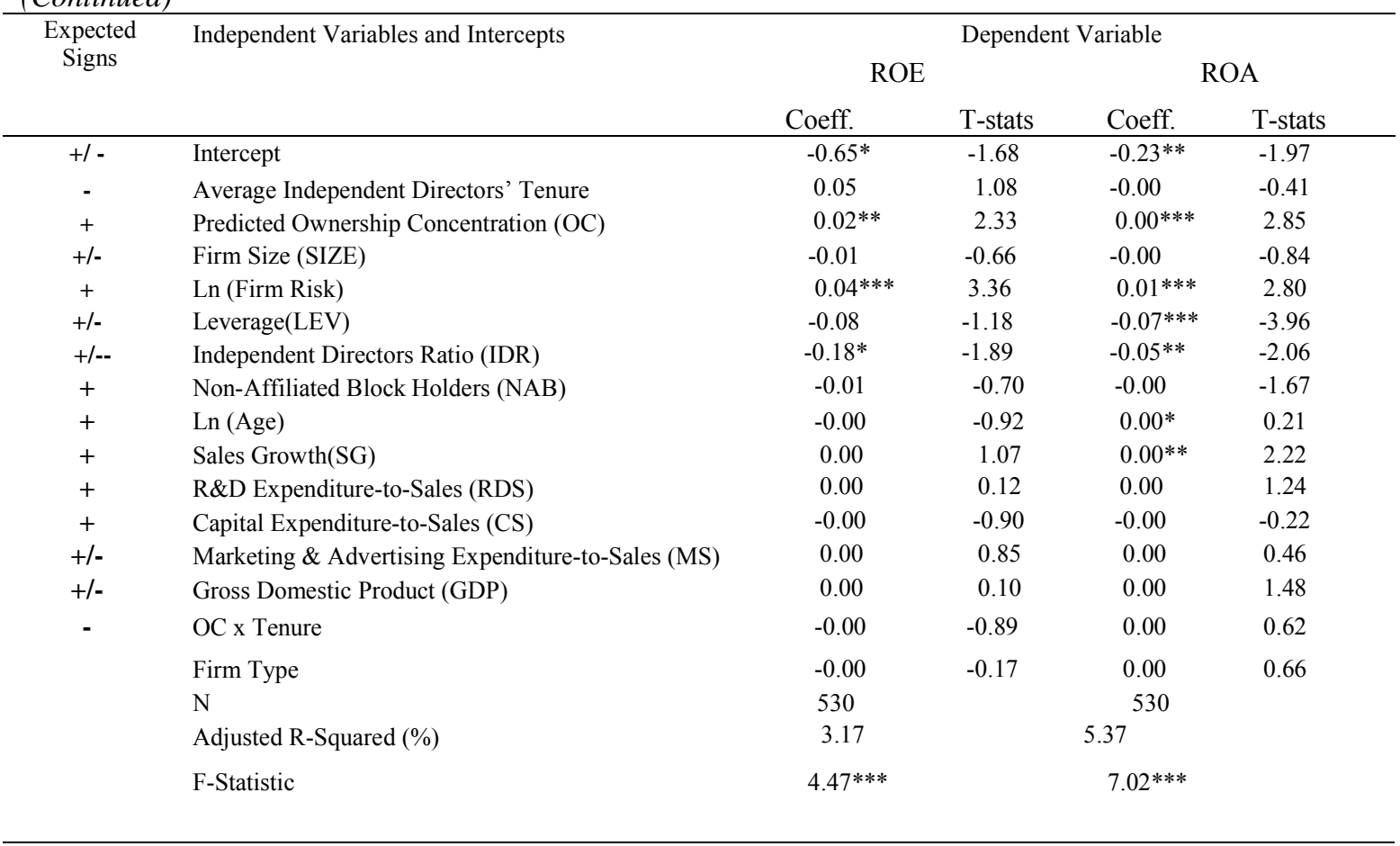

Table 18

Actual Regression Results (Main Results) Normal OLS Regression Fixed Effects Model (Family Firms \& NonFamily Firms) (Continued)

\begin{tabular}{|c|c|c|c|c|c|}
\hline \multirow{3}{*}{$\begin{array}{l}\text { Expected } \\
\text { Signs }\end{array}$} & \multirow[t]{3}{*}{ Independent Variables and Intercepts } & \multicolumn{4}{|c|}{ Dependent Variable } \\
\hline & & \multicolumn{2}{|c|}{ Tobin's Q } & \multicolumn{2}{|c|}{ MBV } \\
\hline & & Coeff. & T-stats & Coeff. & T-stats \\
\hline$+/-$ & Intercept & $3.18 * * *$ & 7.24 & 1.28 & 1.45 \\
\hline- & Average Independent Directors' Tenure & -0.02 & -1.29 & 0.01 & 0.57 \\
\hline+ & Ownership Concentration (OC) & -0.00 & -0.47 & $0.00 * *$ & 2.34 \\
\hline$+/-$ & Firm Size (SIZE) & $-0.08 * * *$ & -4.16 & $-0.00 * * *$ & -0.18 \\
\hline+ & Ln (Firm Risk) & $0.14 * * *$ & 8.30 & 0.15 & 6.33 \\
\hline$+/-$ & Leverage (LEV) & $0.82 * * *$ & 10.03 & 0.16 & 1.35 \\
\hline$+/--$ & Independent Directors Ratio (IDR) & $-0.35^{* *}$ & -2.39 & -0.28 & -1.16 \\
\hline+ & Non-Affiliated Block Holders (NAB) & $0.03 * * *$ & 1.07 & $0.09 * * *$ & 0.92 \\
\hline+ & $\operatorname{Ln}($ Age $)$ & -0.00 & -2.77 & -0.00 & -3.04 \\
\hline+ & Sales Growth(SG) & 0.00 & 0.26 & 0.00 & 0.49 \\
\hline+ & R\&D Expenditure-to-Sales(RDS) & -0.00 & -0.12 & -0.01 & -0.62 \\
\hline+ & Capital Expenditure-to-Sales (CS) & -0.00 & -0.09 & 0.00 & 0.22 \\
\hline$+/-$ & $\begin{array}{l}\text { Marketing \& Advertising } \\
\text { Expenditure-to-Sales (MS) }\end{array}$ & 0.00 & 0.34 & 0.00 & 0.21 \\
\hline \multirow[t]{4}{*}{-} & OC $x$ Tenure & 0.00 & 1.34 & -0.00 & -0.52 \\
\hline & Firm Type & $-0.24 * * *$ & -4.18 & $-0.50 * * *$ & -3.47 \\
\hline & Adjusted R-Squared (\%) & 13.84 & & 8.28 & \\
\hline & F-Statistic & $16.96 * * *$ & & $9.96 * * *$ & \\
\hline
\end{tabular}


Table 19

Actual Regression Results (Main Results) Normal OLS Regression Fixed Effects Model (Family Firms and NonFamily Firms) (Continued)

\begin{tabular}{|c|c|c|c|c|c|}
\hline \multirow{2}{*}{$\begin{array}{c}\text { Expected } \\
\text { Signs }\end{array}$} & \multirow[t]{2}{*}{ Independent Variables and Intercepts } & \multicolumn{4}{|c|}{ Dependent Variable } \\
\hline & & \multicolumn{2}{|c|}{$\mathrm{ROE}$} & \multicolumn{2}{|c|}{$\mathrm{ROA}$} \\
\hline$+/-$ & Intercept & $-0.65^{*}$ & -1.68 & $-0.23 *$ & -1.93 \\
\hline- & Average Independent Directors' Tenure & 0.05 & 1.08 & -0.00 & -0.38 \\
\hline+ & Predicted Ownership Concentration (OC) & $0.02 * *$ & 2.33 & $0.00 * * *$ & 2.89 \\
\hline+ & Ln(Firm Risk) & 0.04 & 3.35 & $0.01 * * *$ & 2.78 \\
\hline$+/-$ & Leverage(LEV) & -0.08 & -1.18 & -0.07 & -4.02 \\
\hline$+/-$ & Independent Directors Ratio (IDR) & $-0.18^{*}$ & -1.90 & $-0.05 * *$ & -2.02 \\
\hline+ & Non-Affiliated Block Holders (NAB) & -0.01 & -0.71 & -0.00 & -1.69 \\
\hline+ & Ln(Age) & -0.00 & -0.92 & $0.00 *$ & 0.21 \\
\hline$+/-$ & Marketing \& Advertising Expenditure-to-Sales (MS) & 0.00 & 0.85 & 0.00 & 0.47 \\
\hline \multirow[t]{4}{*}{-} & OC $x$ Tenure & -0.00 & -0.89 & 0.00 & 0.59 \\
\hline & Firm Type & -0.00 & -0.17 & 0.00 & 0.67 \\
\hline & Adjusted R-Squared (\%) & 3.12 & & 5.53 & \\
\hline & F-Statistic & $4.20 * * *$ & & $6.81^{* * *}$ & \\
\hline
\end{tabular}

\section{Discussion}

We had examined only two types of performance measures which were market-based or accounting-based performance measures. Both these two measures revealed contradictory significant research results. It suggested that accounting-based measures of firm performance are susceptible to management manipulation (Chakravarthy, 1986; Lubatkin \& Shrieves, 1986; Purkayastha, 2013) because these performance measures were oriented towards historical information. Consequently, it could be observed that there was a higher sensitivity of marketbased measures of firms' performances towards agency problem type II (principal-principal conflict) in family firms as evidenced by the significant negative relationship between average tenure of independent directors and market-based measures of firm performance (MBV). Moreover, it indicated to the significant positive moderating effect of controlling shareholders' ownership on this relationship within market-based measures of firm performance (MBV). The higher sensitivity of market-based measures of firm performance towards agency problem type II (principal-principal conflict) is consistent with the finding of Mollah, Farooque, and Karim (2012) who found that shareholders in emerging markets used their ow $\mathrm{n}$ discretion where necessary to increase the amount of discount in the market valuations of firms if they had a positive or negative perception of the firms' performances and they were less attracted to accounting-based measures of firm performance which were prone to call them accounting manipulations. Overall, it was observed that among Malaysian firms (i.e. within Malaysian family firms in exclusive industries) expropriation occurred as a result of long tenure of independent directors. The likelihood of expropriation occurrence reduced MBV. Thus, the first hypothesis was supported but only for market-based measures of performance. However, the findings could not show that expropriation due to long tenure of independent directors which reduced $\mathrm{MBV}$ and was stronger in family firms compared to non-family firms 
within the context of the Malaysian institutional setting. Hence, the second hypothesis was not supported except for market- based measures of firm performance. The findings of the study also referred to the significant positive moderating effect of controlling shareholders' ownership on expropriation as the tenure of independent directors increased within Malaysian firms within family firms in exclusive industries. However, this was restricted to market- based measures of firm performance (i.e. MBV). Therefore, the third hypothesis was supported but only for marketbased performance measures of firm value. It also could not be shown that this significant positive moderating effect which increased MBV was stronger in family firms compared to nonfamily firms. Finally, the fourth hypothesis was not supported except for market-based performance measures of firm value. The total inability to support the second and fourth hypotheses suggested that attention on minority shareholder expropriation problems particularly due to long tenure of independent directors in Malaysia ought to focus both on family firms as well as non-family firms. Another important implication of these findings was that reputational effects helped reduce expropriation due to long tenure of independent directors by exhibiting a significant positive moderating effect of controlling shareholders' ownership on expropriation. Peng and Jiang (2010) argued that reputational effects were poor substitutes for institutional deficiencies to protect the rights of low minority shareholders particularly in emerging markets. Our findings also offered practical tips for effective post Transmile and the framework of global financial crisis.

\section{Conclusion}

Generally, this study showed that minority shareholder expropriation due to long tenure of independent directors exists within Malaysian family firms in exclusive industries. This possibly suggested that Malaysian family firms in exclusive industries might encounter it in competitive markets less and as a result their independent directors were less concerned in evaluating the performance of their CEOs (Young, Stedham, \& Beekun, 2000). This provided opportunities for family controlling shareholders to increase their influences on the independent directors as they served longer on the board, through their CEOs who were basically hired by them and ultimately increased their own level of expropriation; therefore, it reduced the firm value. However, it could not be proven whether expropriation due to the long tenure of independent directors was stronger in family firms compared to non-family firms within the context of the Malaysian institutional setting. On the other hand, the family controlling shareholders' ownership had a significant positive moderating effect on the relationship between independent directors' tenure and firm value in Malaysian family firms within exclusive industries. It suggested that the reputational effects within family firms were able to reduce the minority shareholder expropriation in these firms particularly in Transmile posts. This brings a new dimension to agency theory by showing that corporate reputational effects was able to reduce minority shareholder expropriation in family firms within exclusive industries during the global financial crisis. Peng and Jiang (2010) referred to the significant positive moderating effect which brought into dispute the argument that reputational effects were poor substitutes for the institutional deficiencies in emerging markets of Malaysia. The findings of this study also indicated that there was a significant negative relationship between 
independent directors' tenure and firm value as found in family firms in exclusive industries. Furthermore, it suggested that the Malaysian Code of Corporate Governance (MCCG) 2012 could only limit the independent directors' tenure to a maximum of nine years. This recommendation should particularly target the family firms in exclusive industries (comparison of the pre-robustness and robustness test results). The reason was because the comparison of the pre-robustness and robustness test results showed that long tenure of the independent directors reduced the firm value in family firms. Lastly, future research could consider analyzing the effects of state legislation on expropriation of minority shareholders particularly in emerging markets.

\section{References}

Abdelsalam, O., \& El-Masry, A. (2008). The impact of board independence and ownership structure on the timeliness of corporate internet reporting of Irish-listed companies. Managerial Finance, 34(12), 907 - 918.

Aguilera, R. V., \& Cuervo-Cazurra, A. (2009). Codes of good governance. Corporate Governance: An International Review, 17(3), $376-387$.

Ahrens, T., Filatotchev, I., \& Thomsen, S. (2011). The research frontier in corporate governance. Journal of Management \& Governance, 15(3), 311-325.

Anderson, R. C., Mansi, S. A., \& Reeb, D. M. (2004). Board characteristics, accounting report integrity, and the cost of debt. Journal of Accounting and Economics, 37(3), 315 - 342.

Anderson, R. C., \& Reeb, D. M. (2003). Founding-family ownership and firm performance: Evidence from the S \& P 500. The Journal of Finance, 58(3), $1301-1328$.

Andres, C. (2008). Large shareholders and firm performance: An empirical examination of founding-family ownership. Journal of Corporate Finance, 14(4), 431- 445.

Baltagi, B. H., Bresson, G., \& Pirotte, A. (2008). The econometrics of panel data. Advanced Studies in Theoretical and Applied Econometrics, 46, 517-546.

Bebchuk, L. A., Fried, J. M., \& Walker, D. I. (2002). Managerial power and rent extraction in the design of executive compensation. The University of Chicago Law Review, 69(3), 751-846.

Bebchuk, L. A., \& Fried, J. M. (2003). Executive compensation as an agency problem. The Journal of Economic Perspectives, 17(3), 71-92.

Bjuggren, C. M., Johansson, D., \& Sjogren, H. (2011). A note on employment and gross domestic product in Swedish familyowned businesses. Family Business Review, 24(4), 362-371.

Canavan, J., Jones, B., Potter, M. J. (2004). Board tenure: How long is too long? Boards \& Directors, $28(2), 39-42$.

Capon, N., Farley, J., \& Hoening, S. (1996). Toward an integrative explanation of corporate financial performance. Boston, MA: Kluwer Academic Publishers.

Cascino, S., Pugliese, A., Mussolino, D., \& Sansone, C. (2010). The influence of family ownership on the quality of accounting information. Family Business Review, 23(3), 246-265.

Chakrabarty, S. (2009). The influence of national culture and institutional voids on family ownership of large firms: A country level empirical study. Journal of International Management, 15(1), 32-45.

Chakravarthy, B. S. (1986). Measuring strategic performance. Strategic Management Journal, 7(5), 437-458.

Claessens, S., Djankov, S., Fan, J. P. H., \& Lang, L. H. P. (2002). Disentangling the incentive and entrenchment effects of large shareholdings. Journal of Finance, 57(6), 2741-2771.

Claessens, S., Djankov, S., \& Lang, L. (2000). The separation of ownership and control in East Asian corporations. Journal of Financial Economics, 58(1/2), 81-112.

Demsetz, H., \& Lehn, K. (1985). The structure of corporate ownership: Causes and consequences. The Journal of Political Economy, 93(6), 1155-1177.

Faccio, M., Lang, L. H. P., \& Young, L. (2001). Dividends and expropriation. The American Economic Review, 91(1), 5478.

Gul, F. A., Kim, J. B., \& Qiu, A. A. (2010). Ownership concentration, foreign shareholding, audit quality, and stock price synchronicity: Evidence from China. Journal of Financial Economics, 95(3), 425-442. 
Gomez, E. T. (1999). Chinese business in Malaysia: Accumulation, ascendance, accommodation. Honolulu: University of Hawaii Press.

Gujarati, D. N., \& Porter, D. C. (2009). Basic econometrics (5 $5^{\text {th }}$ ed.). Boston: McGraw-Hill.

Haniffa, R., \& Hudaib, M. (2006). Corporate governance structure and performance of Malaysian listed companies. Journal of Business Finance \& Accounting, 33(7/8), 1034-1062.

Hausman, J. A. (1978). Specification tests in econometrics. Econometrica, 46, 1251-1271.

Heugens, P. M. A. R., Essen, M. V., \& Oosterhout, J. V. (2009). Meta-analyzing ownership concentration and firm performance in Asia: Towards a more fine-grained understanding. Asia pacific Journal of Management, 26(3), 481-512.

Himmelberg, C. P., Hubbard, R. G., \& Palia, D. (1999). Understanding the determinants of managerial ownership and the link between ownership and performance. Journal of Financial Economics, 53(3), 353-384.

Holderness, C. G., \& Sheehan, D. P. (1988). The role of majority shareholders in publicly held corporations: An exploratory analysis. Journal of Financial Economics, 20(1/2), 317-346.

Ibrahim, H. (2009). Family-ownership and performance: Evidence from Malaysian public listed companies (Unpublished doctoral thesis). University Malaya, Kuala Lumpur.

Ishak, Z., \& Napier, C. (2006). Expropriation of minority interests and corporate diversification in Malaysia. Asian Academy of Management Journal of Accounting and Finance, 2(1), 85-113.

Jensen, M., \& Meckling, W. (1976). Theory of the firm: Managerial behavior, agency costs, and ownership structure. Journal of Financial Economics, 3(4), 305-360.

Jiang, G., Lee, C. M. C., \& Yue, H. (2010). Tunneling through inter corporate loans: The China experience. Journal of Financial Economics, 98(1), 1-20.

Jiang, Y., \& Peng, M. W. (2011). Principal-principal conflicts during crisis. Asia Pacific Journal of Management, 28(4), 683695.

Johnson, S., Porta, R. L., Lopez-de-Silanes, F., \& Shleifer, A. (2000). Tunneling. American Economic Review, 90(2), $22-27$.

Klapper, L. F., \& Love, I. (2004). Corporate governance, investor protection and performance in emerging markets. Journal of Corporate Finance, 10(5), 703-728.

Krishnamurti, C., Sevic, A., \& Sevic, Z. (2005). Legal environment, firm-level corporate governance and expropriation of minority shareholders in Asia. Economics of Planning, 38(1), 85-111.

Kunst, R. M. (2009). Econometrics for panel data. Working Paper. University of Vienna. Research website: http:// homepage. univie. ac. at/Robert. Knust/panel 2e.pdf.

La Porta, R., Lopez-de-Silanes, F., Shleifer, A., \& Vishny, R. (2000). Investor protection and corporate valuation. Journal of Financial Economics, 58(1/2), 3-27.

Loy, T. C. J. (2010). Dynasting across cultures: A grounded theory of Malaysian and Chinese family firms (Unpublished doctoral dissertation) University of Minnesota, US.

Lubatkin, M., \& Shrieves, R. E. (1986). Towards reconciliation of market performance measures to strategic management research. Academy of Management Review, 11(3), 497-512.

Mishkin, F. S. (2013). The economics of money, banking, and financial markets (3 ${ }^{\text {rd }}$ ed.): Boston: Addison-Wesley.

Mitton, T. (2002). A cross-firm analysis of the impact of corporate governance on the East Asian financial crisis. Journal of Financial Economics, 64(2), 215-241

Mollah, S., Farooque, O. A., \& Karim, W. (2012). Ownership structure, corporate governance and firm performance: Evidence from an African emerging market. Studies in Economics \& Finance, 29(4), 301-319.

Morck, R., \& Yeung, B. (2003). Agency problems in large family business groups. Entrepreneurship, Theory, \& Practice, 27(4), $367-382$.

Morck, R., Wolfenzon, D., \& Yeung, B. (2005). Corporate governance, economic entrenchment, and growth. Journal of Economic Literature, 43(3), 655-720.

Peng, M. W., \& Jiang, Y. (2010). Institutions behind family ownership and control in large firms. Journal of Management Studies, 47(2), 253-273.

Porter, M. E. (1980). Competitive strategy: Techniques for analyzing industries and competitors. New York, USA: Free Press.

O'Reilly, C. A., \& Caldwell, D. F. (1981). The commitment and job tenure of new employees: Some evidence of post decisional justification. Administrative Science Quarterly, 26(4), 597-616. 
Reddy, K., Locke, S., \& Scrimgeour, F. (2010). The efficacy of the principle-based corporate governance practices and firm financial performance: An empirical investigation. International Journal of Managerial Finance, 6(3), $190-219$.

Sarkar, J., \& Sarkar, S. (2000). Large shareholder activism in corporate governance in developing countries: Evidence from India. International Review of Finance, 1(3), 161-194.

Salancik, G. (1977). Commitment and control of organizational behavior and belief. In B.Staw \& G.Salancik (Eds.), New directions in organizational behavior (pp. 1-54). Chicago: St. Claire Press.

Schulze, W. S., Lubatkin, M. H., \& Dino, R. N. (2003). Toward a theory of agency and altruism in family firms. Journal of Business Venturing, 18(4), 473-490.

Shim, D. S. (2006). Governance in the markets: Malaysian perspective. Journal of Financial Crime, 13(3), 300-322.

Short, H. (1994). Ownership, control, financial structure, and the performance of firms. Journal of Economic Surveys, 8(3), 203-249.

Vafeas, N. (2003). Length of board tenure and outside director independence. Journal of Business Finance \& Accounting, 30(7/8), 1043-1064.

Xu, X., \& Wang, Y. (1997). Ownership structure, corporate governance, and corporate performance: The case of Chinese stock companies (World Bank Policy Research Working Paper No. 1794). Retrieved from World Bank, Economic Development Institute. Research Website: http:// ssrn.com/abstract=45303

Villalonga, B., \& Amit, R. (2006). How do family ownership, control and management affect firm value? Journal of Financial Economics, 80(2), 385-417.

Wahab, E. A. A., How, J. C. Y., \& Verhoeven, P. (2007). The impact of the Malaysian Code on Corporate Governance: Compliance, institutional investors and stock performance. Journal of Contemporary Accounting \& Economics, 3(2), 106129.

Wahab, E., Haron, H., Char, L. L., \& Yahya, S. (2011). Does corporate governance matter? Evidence from related party transactions in Malaysia. Advances in Financial Economics (International Corporate Governance), 14, 131-164.

Yermack, D. (1996). Higher market valuation of companies with a small board of directors. Journal of Financial Economics, 40(2), 185-211.

Young, G. J., Stedham, Y., \& Beekun, R. I. (2000). Boards of directors and the adoption of a CEO performance evaluation process: Agency and institutional Theory perspectives. Journal of Management Studies, 37(2), 277-296.

Young, M. N., Peng, M.W., Ahlstrom, D., Bruton, G. D., \& Jiang, Y. (2008). Corporate governance in emerging economies: A review of the principal-principal perspective. Journal of Management Studies, 45(1), 196-220.

Yunos, R. M., Smith, M., \& Ismail, Z. (2010). Accounting conservatism and ownership concentration. Journal of Business \& Policy Research, 5(2), 1-15. 